International Journal of Electrical Engineering and Technology (IJEET)

Volume 11, Issue 4, June 2020, pp. 181-190, Article ID: IJEET_11_04_021

Available online at https://iaeme. com/Home/issue/IJEET? Volume $=11 \&$ Issue $=4$

ISSN Print: 0976-6545 and ISSN Online: 0976-6553

DOI: https://doi.org/10.34218/IJEET.11.4.2020.021

\title{
ENHANCED STEP UP ENERGETIC-TURN ON CAPACITOR/ TURN ON-INDUCTOR QUASI-Z- SOURCE INVERTERS FOR COMMERCIAL APPLICATIONS
}

\author{
M. Padmapriya* \\ Associate Professor, Department of Electrical and Electronics Engineering, \\ SMK Fomra Institute of Technology, Chennai, Tamilnadu, India

\section{Dr. T.A. Raghavendiran} \\ Dean and Professor, Sri Venkataeswara Engineering College for Women, \\ Tirupathi, India \\ *Corresponding Author Email: priyajegadeesh28@gmail.com
}

\begin{abstract}
This paper implies a novel network on enhanced step up energetic-turn oncapacitor/turn on-inductor quasi-Z-source inverter (ENTC/TL-QZSI) for commercial applications, in which a conventional QZSI network is considered as a basic model. When compared with other QZSI-based networks under the same operating manner, the proposed ENTCC/TL-QZSI produces greater stepping up rate, requires lesser passive components such as inductors and capacitors, and bears reduced voltage stress over the turn on and off devices of the inverter. Additional merit for this circuit is its enhancing capability. When more stepping up rate is required, then more blocks can easily be inter linked at the impedance circuit by including one inductor and three diodes. Both the simulation studies and the experimental outputs attained from a prototype model clearly and explain proper working and characteristics performance of the proposed ENTC/TL-QZSI.
\end{abstract}

Key words: ENTC/TL-QZSI Enhanced step up energetic-turn on-capacitor/turn on inductor-Quasi Z source inverter

Cite this Article: M. Padmapriya and Dr. T.A. Raghavendiran, Enhanced Step Up Energetic-Turn on Capacitor/Turn on-Inductor Quasi-Z-Source Inverters for Commercial Applications. International Journal of Electrical Engineering and Technology, 11(4), 2020, pp. 181-190.

https://iaeme.com/Home/issue/IJEET?Volume $=11 \&$ Issue $=4$ 


\section{INTRODUCTION}

The quasi z-source inverter (QZSI) is a single stage power converter reframed from Z-source inverter network, applying a unique impedance circuit. The ordinary VSI and CSI suffers from the drawbacks that firing two switches in the same leg or phase exhibits a short and also the maximum achievable voltage at the output will not be greater than the input $\mathrm{dc}$ and they are buck converters. Both Z-source inverters and quasi-Z-source inverters to win these demerits; by using more number of shoot-through zero states. A zero state is shown when the upper three or lower three switches are triggered at the same instant to step up the output voltage. Keeping the six allowable energetic conducting states of a VSI, depending upon the voltage stepping up requirements the zero states can be slightly or fully replaced by the shoot through modes. Quasi-Z-source inverters (QZSI) exhibit all the merits of conventional Z source inverter. To produce voltage boost and inversion in a single stage the impedance network links the source and the inverter. It is capable of managing a wide range of input DC voltage By using this new network, the inverter draws a steady current from the PV array. It needs low power component, PV panels switching ripples are minimized and less EMI problems are produced and reduction in source stress compared to the conventional ZSI. The paper explains the voltage enhancement property of the $\mathrm{Z}$ source Inverter. The block diagram of this system contains an input DC Supply, a switched Inductor/Capacitor network, three phase inverter and three phase load in addition with the isolation circuit.

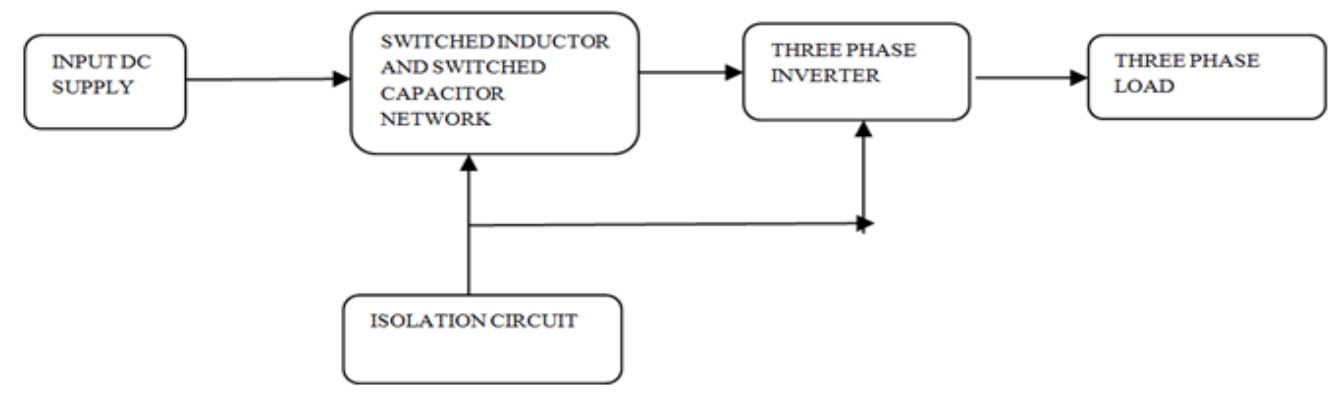

Figure 1 Layout of the network

\subsection{Quasi Z Source Network}

The inductive and capacitive impedance network that interconnects the source and inverter slightly varies in case of QZSI network when checked with a traditional ZSI. The LC and diode network coupled to the inverter bridge modifies the working of the circuit, permitting the shoot-through state which is prohibited in conventional VSI.[2]

This topology will completely safeguard the circuit from dangers during shoot through mode and only in the shoot-though mode, the QZSI-network raises the dc-link voltage.

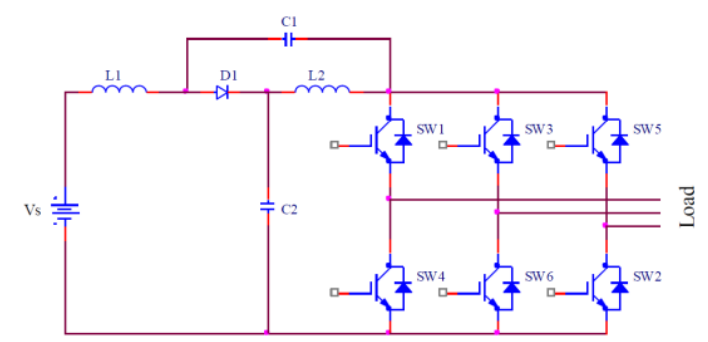

Figure 2 LC impedance network connecting source and inverter 
The impedance topology of QZSI uses of inductors and capacitors to provide an impedance source, linking the converter to the dc source at the input. The DC source can be a PV array. The QZSI topology is shown in the figure 2.1.

\section{WORKING PRINCIPLE AND EQUIVALENT CIRCUIT OF QZSI}

The two states of working of a quasi z-source inverter are:

(1) Non-shoot through state (active state).

(2) Shoot through state.

\subsection{Active State}

In the active state, the triggering pattern for the switches in the QZSI is same as that of a traditional VSI. The inverter bridge from the input side is equivalent to a current source, the input dc voltage is available as DC link voltage that is feed as an input to the inverter, which makes the QZSI to behave like a traditional VSI.[3]

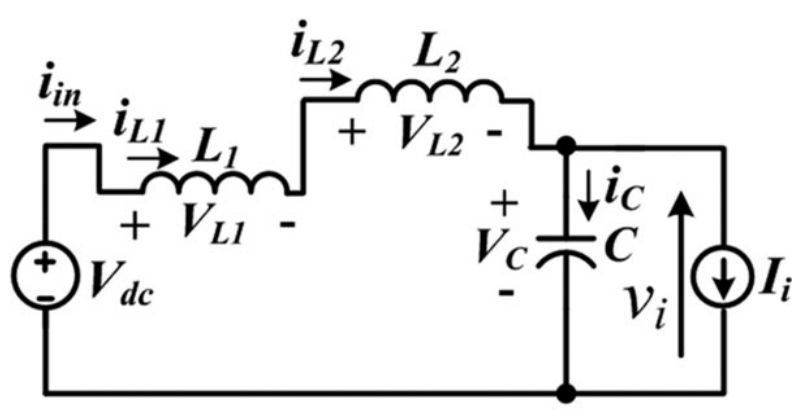

Figure 3 Equivalent circuit of QZSI in energetic state

\subsection{Shoot through State}

For a very short time interval the switches of the same leg in the inverter bridge are triggered simultaneously in the shoot through state. The source does not get short circuited due to the presence LC network. For a given value of modulation index and duty cycle ratio, the DC link voltage during the shoot through states, is maximized by a boost factor when the output voltage is increased.[4]

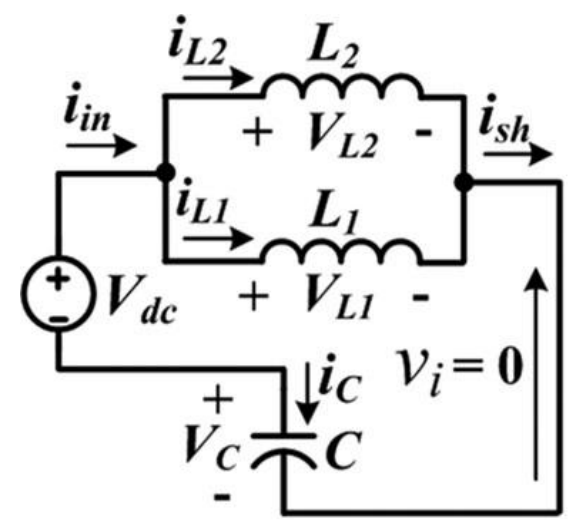

Figure 4 In shoot through mode-Equivalent circuit of QZSI

\subsection{Impedance Network Design}

\subsubsection{Design of Capacitor}


To maintain a fair constant voltage, the capacitor is designed to assimilate the voltage ripple. The current passing through the capacitor is equal to the current in the inductor during shootthrough state as the capacitor charges the inductors, therefore across the capacitor voltage ripple is:

$\mathrm{V}_{\mathrm{C}}=\frac{4-\sqrt{3} M a}{3 \sqrt{3} M a-4} \mathrm{~V}_{\mathrm{dc}}$

\section{QUASI Z SOURCE INVERTER AND ITS IMPROVED TOPOLOGY}

A conventional QZSI and improved topology with input current as a continuous one is shown in Fig. 5 shows the normal QZSI, which assures input current as a continuous one as well as lowers voltage stress on capacitors.[6]The ratio between the peak dc-link voltage across the inverter bridge ^ $v i$ and the dc input voltage $V \mathrm{dc}$, is defined as boost factor and is expressed as:

$B=\frac{\stackrel{v i}{V d c}}{V d c}=\frac{1}{1-2(T \operatorname{sh} / T)}=\frac{1}{1-2 D s h}$

where $T_{\text {sh }}$ is the time where two switches of the same leg conduct at the same time interval during switching period $T$ and during shoot-through duty ratio, Dsh is the duty cycle.

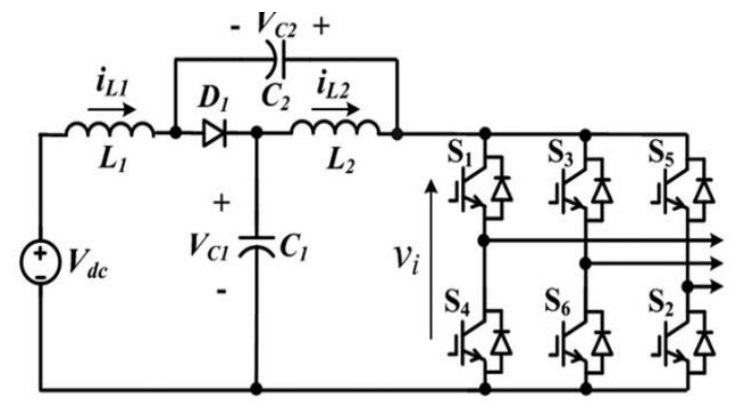

Figure 5 Traditional QZSI

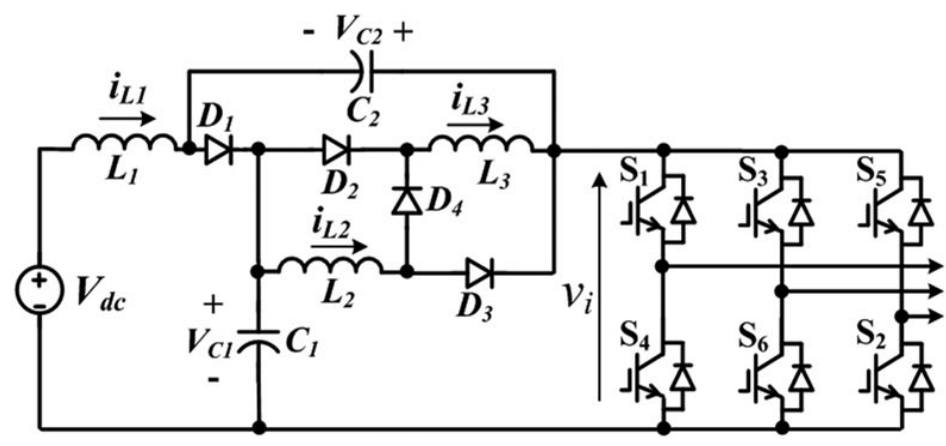

Figure 6 TL-QZSI

In Fig.6 a different network based on QZSI also called as an TL-QZSI, is shown. It has a turned on-inductor structure at the QZSI in order to enhance the boost factor of the TL-QZSI, and its corresponding boost factor can be derived as:

$B=\frac{1+D s h}{1-2 D \operatorname{sh}-(\mathrm{Dsh} * \mathrm{Dsh})}$ 


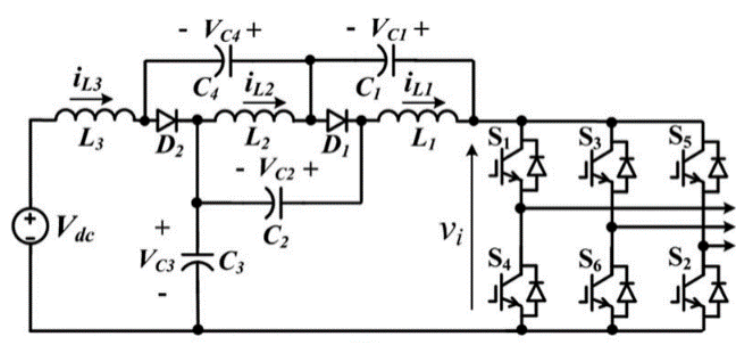

Figure 7 Continuous-current CA-QZSI

In the Fig. 7 proposed network is shown and named as a enhanced-boost QZSI (CAQZSI) with continuous-current capacitor-assistance.[5] They can be enhanced to have very large stepping up of voltage by linking more stages. CA-QZSI's boost factor can be derived respectively, as follows:

$B=\frac{1}{1-3 D s h}$

\section{PROPOSED NETWORKS BASED ON ENSC-QZSI}

Two new types of topologies, namely, basic ENSC-QZSI and ENSC/TL-QZSI are proposed. The working principles for each topology are described below.

\subsection{Basic Ensc-Qzsi}

Fig. 8 represents the basic ENSC-QZSI in which an Z network consisting of one energetic switch $(S 7)$, two diodes $(D i, D b)$ one capacitor $(C)$ and one inductor $(L 1)$ that connects the inverter bridge to the input dc voltage source. This network does not take part in the inverter and the negative terminal between the dc input voltage source. The ENSC-QZSI apart from the six active states and two zero states have an extra shoot through state like the traditional QZSI. For analysis, the operating states can be simplified to non shoot-through and shootthrough states from the three operating modes.

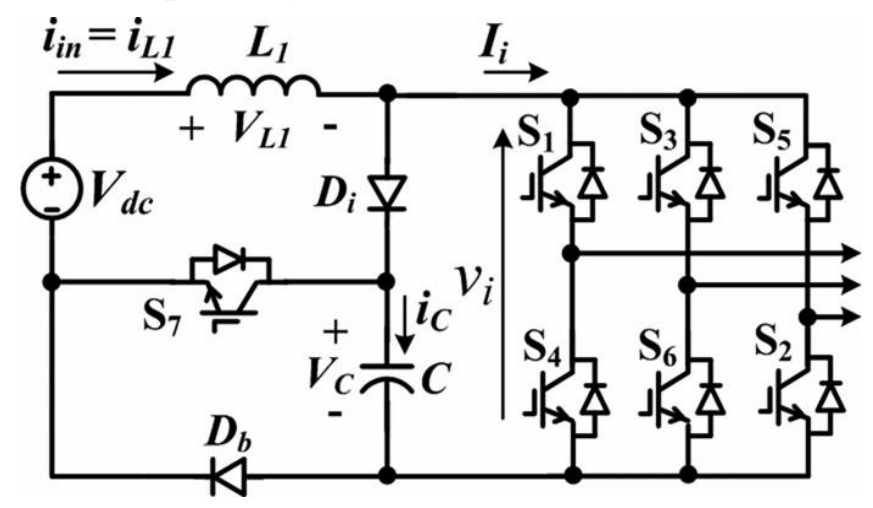

Figure 8 Basic ESC-QZSI

As shown in Fig 8 in the shoot through mode a the upper and lower switching devices of any phase legs are conducting at the same time interval and the load terminals are shorted during this mode the switching device $S 7$ is turned ON. The diodes $D i$ and $D b$ are OFF during this state. The inductor $L 1$ saves energy from both the dc input source and capacitor $C$ as the capacitor $C$ discharges through switching device $S 7$ and the inverter bridge. we have:

$$
\begin{aligned}
& V_{L 1}=V_{\mathrm{dc}}+V_{c} \\
& i_{c}=-i_{L 1}
\end{aligned}
$$


$v i=0$.

In Fig. 9, The non shoot-through state is shown in. the proposed inverter has two zero states and six energetic vectors. The switching device $S 7$ is turned off during this mode, whereas the diodes $D i$ and $D b$ are $\mathrm{ON}$. The inductor $L 1$ transfers energy from the dc input source to the inverter while the capacitor $C$ is charged, and the. From Fig. 9, we have:

$$
\begin{aligned}
& V_{L 1}=V_{d c}-V_{c} \\
& i_{c}=i_{L 1}-I_{i} \\
& V_{i}=V_{c}
\end{aligned}
$$

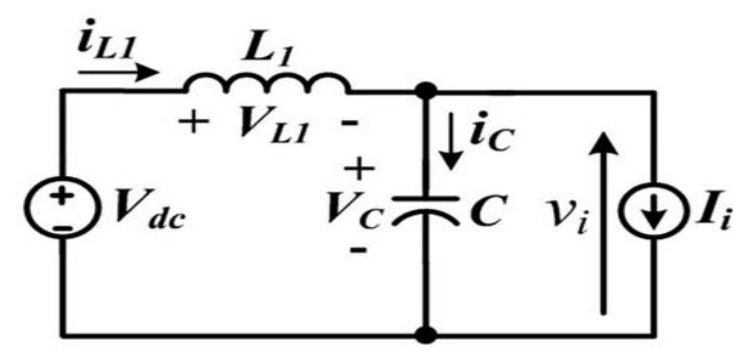

Figure 9 Non Shoot- through state

In this state, As the capacitor voltage is usually greater than the dc input voltage, the inductor voltage VL1 posses a negative value, because and also across the inverter bridge, the peak dc-link voltage "vi is the same as the capacitor voltage. To the inductor L1 from (11) and (12) over one switching period Tson applying the voltage second balance principle, the following relationship can be derived:

DshTs $(\mathrm{Vdc}+\mathrm{Vc})+(1-\mathrm{Dsh}) \mathrm{Ts}(\mathrm{Vdc}-\mathrm{Vc})=0$.

From (4.7), the voltage across the capacitor can be expressed as

$\mathrm{Vc}=\frac{1}{1-2 D s h} \mathrm{Vdc}$.

Similarly, the average of the inductor current or the input current applying the amperesecond balance principle to the capacitor $\mathrm{C}$, can be derived as:

$$
{ }^{-} \text {iL1 }=- \text { iin }=\frac{1-D s h}{1-2 D s h}(\text { Ii }) \text {. }
$$

Because the capacitor voltage $\mathrm{Vc}$ and the peak dc-link voltage across the inverter bridge vi is the same as at the ENSC- QZSI, by using (14), a boost factor of the inverter can be derived as:

$$
\mathrm{B}=\frac{v i}{V d c}=\frac{V c}{V d c}=\frac{1}{1-2 D s h}
$$

The boost factor of a basic ENSC-QZSI is the same as that of a conventional QZSI.

\subsubsection{Ensc/TL-Qzsi}

One cell containing one inductor and three diodes is added to the ENSC-QZSI in order to enhance the boost factor. This network is called as the ENSC/TL-QZSI. Fig 11 shows the equivalent circuits of the ENSC/TL-QZSI in the shoot-through mode and non shoot-through mode, respectively. 
In the shoot-through mode, as shown in Fig. 13, the switching device $S 7$ is turned on and the inverter bridge is shorted, as in the case of basic ESC-QZSI. During the shoot-through state, the diodes $D 1$ and $D 2$ are ON, whereas in OFF position the diode $D i, D b$, and $D 3$ are present. In Parallel the inductors $L 1$ and $L 2$ are connected.

Therefore when the capacitor $C$ is discharged, the inductors store energy from both the dc input source $V \mathrm{dc}$ and capacitor $C$ through $S 7$ and through the inverter bridge. From Fig. 10, we have,

$$
\begin{aligned}
& \mathrm{VL} 1(\mathrm{ST})=\mathrm{VL} 2(\mathrm{ST})=\mathrm{Vdc}+\mathrm{Vc} \\
& \mathrm{ic}=-(\mathrm{iL} 1+\mathrm{iL} 2) \\
& \mathrm{vi}=0 .
\end{aligned}
$$

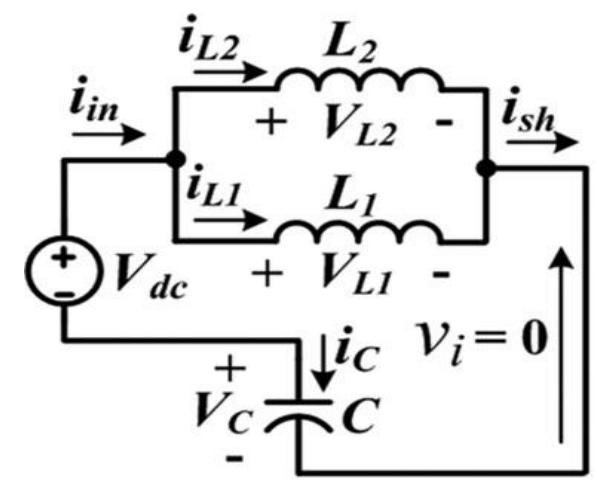

Figure 10 Equivalent circuit of ENSC/TL-QZSI in shoot-through mode

The non shoot-throughmode, as shown in Fig. 11, the load side is supplied by the inverter voltages, and the switching device $S 7$ is turned off. During this state, the diodes $D i, D b$, and $D 3$ are $\mathrm{ON}$, whereas the diodes $D 1$ and $D 2$ are OFF. The inductors $L 1$ and $L 2$ are linked in series. The dc input voltage and two inductors transfers energy to both the inverter and the capacitor through diodes $D 3, D i$, and $D b$. Thus, the capacitor $C$ is charged. From Fig. 12, we have:

$$
\begin{aligned}
& \mathrm{VL} 1(\mathrm{NST})=\mathrm{Vdc}-\mathrm{Vc}-\mathrm{VL} 2(\mathrm{NST}) \\
& \mathrm{VL} 2(\mathrm{NST})=\mathrm{Vdc}-\mathrm{Vc}-\mathrm{VL} 1(\mathrm{NST}) \\
& \mathrm{ic}=\mathrm{iL} 1-\mathrm{Ii}=\mathrm{iL} 2-\mathrm{Ii} \\
& \mathrm{vi}=\mathrm{Vc} .
\end{aligned}
$$

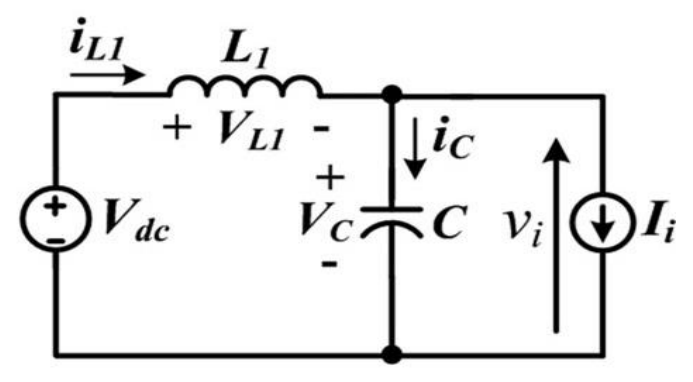

Figure 11 Non shoot-through state 


\subsubsection{Equivalent circuit of Ensc/TL-Qzsi}

Over one switching period $T s$, the voltage across $L 1$ during the non shoot-through mode on applying the voltage-second balance principle to the inductor $L 2$ from (21) and (22) is derived as:

$$
V_{L 1}(\mathrm{NST})=\frac{1}{1-D s h} V \mathrm{dc}+\frac{2 D s h-1}{1-D s h} V_{c}
$$

The capacitor voltage can be derived by applying the voltage-second balance principle to the inductor $L 1$ from (20) and (22), as:

$$
\mathrm{Vc}=\frac{1+D s h}{1-3 D s h} \mathrm{Vdc}
$$

Using (18), the boost factor of the ESC/SL-QZSI can be expressed as:

$$
\mathrm{B}=\frac{\stackrel{v i}{V d c}}{V d-2(T s h / T)}=\frac{1}{1-2 D s h}
$$

where $1 / 3$ is the maximum shoot-through duty ratio..

Thus, $M a \leq 1.15\left(1-D_{\text {sh }}\right)$ the range of the modulation index is also limited and a maximum constant boost control method that has to be applied. the average of two inductor currents can be derived on applying the ampere-second balance principle to the capacitor $C$, as :

${ }^{-} \mathrm{iL1}={ }^{-} \mathrm{iL2}=\frac{1-D s h}{1-3 D s h}$ Ii .
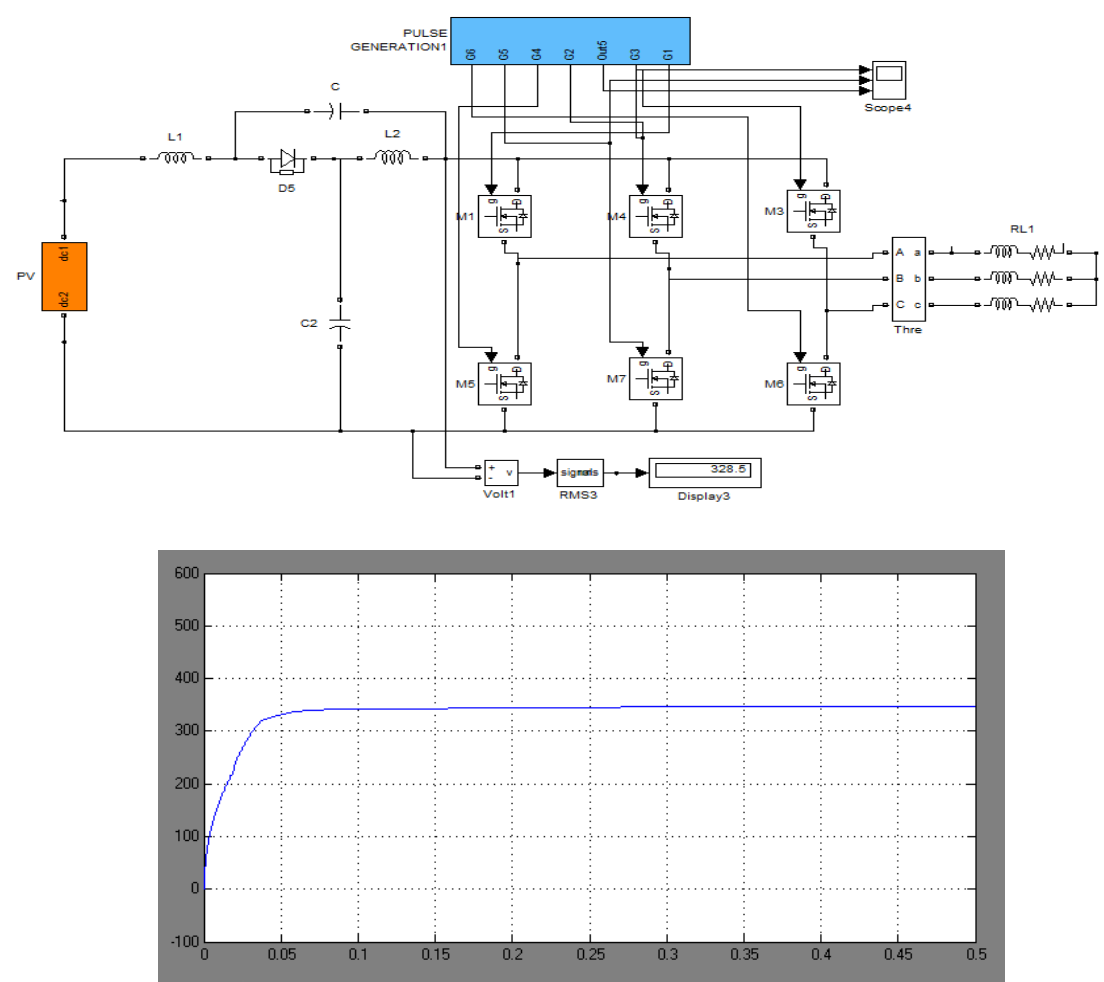

Figure 12 Output voltage Waveform 


\section{CONCLUSION}

This paper proposed a new ENSC/TL-QZSIs based on the QZSI network. In comparison with other networks such as CA-QZSI, DA-QZSI, and SL-QZSI, the proposed ENSC/TLQZSI gives a higher boost factor all over the full range of shoot-through duty ratio. Passive components, such as an inductor and one-three capacitors in the impedance network, are reduced, although one additional switching device is required. The finalized value of inductances required for the proposed ENSC/TL-QZSI is slightly higher than those of both the CA-QZSI and TL-QZSI, and the capacitance value for the proposed network is much lesser than the finalized value of capacitances needed at the other three networks. For the same dc input voltage and ac output voltage. The voltage stress across the switching devices of the main inverter is minimized. Therefore, the weight, cost and size of the power converter can be minimized. In addition to obtain very high boost ability by linking more cells the proposed topology can easily be extended. Where one cell consists of three diodes and only one inductor. As illustrated experimentally, the capacitor voltage is boosted to $280 \mathrm{~V}$ under 20 $\mathrm{V}$ dc input voltage, and the inverter generates line-to line output voltage of $158 \mathrm{Vrms}$. By cascading one cell more to the ENSC/TL-QZSI topology, the ac output voltage can be increased by $11 \%$ at the same boost factor. Both the simulation and the experimental results proves the proper working and performance of the proposed ESC/SL-qZSI. The McENSC/TL QZSI and the ENSC/TL-QZSI can be applied.

\section{REFERENCES}

[1] Ellabban, O., Van Mierlo, J., \& Lataire, P. (2011). Experimental study of the shootthrough boost control methods for the Z-source inverter. EPE journal, 21(2), 18-29.

[2] Shen, M., Wang, J., Joseph, A., Peng, F. Z., Tolbert, L. M., \& Adams, D. J. (2004). Maximum constant boost control of the Z-source inverter. In Conference Record of the 2004 IEEE Industry Applications Conference, 2004. 39th IAS Annual Meeting. (Vol. 1). IEEE.

[3] Peng, F. Z., Shen, M., \& Qian, Z. (2005). Maximum boost control of the Z-source inverter. IEEE Transactions on power electronics, 20(4), 833-838.

[4] Liu, Y., Ge, B., Ferreira, F. J., de Almeida, A. T., \& Abu-Rub, H. (2011). Modeling and SVPWM control of quasi-Z-source inverter. In 11th International Conference on Electrical Power Quality and Utilisation (pp. 1-7). IEEE.

[5] Ali, U. S., \& Kamaraj, V. (2011). A novel space vector PWM for Z-source inverter. In 2011 1st International Conference on Electrical Energy Systems (pp. 82-85). IEEE.

[6] Anderson, J., \& Peng, F. Z. (2008). Four quasi-Z-source inverters. In 2008 IEEE Power Electronics Specialists Conference (pp. 2743-2749). IEEE.

[7] Sabeur, N., Mekhilef, S., Nakaoka, M., \& Masaoud, A. (2016). A simple modulation based maximum boost control strategy for three-phase quasi Z-source inverter. In 2016 IEEE 8th International Power Electronics and Motion Control Conference (IPEMCECCE Asia) (pp. 570-574). IEEE.

[8] Zhu, X., Zhang, B., \& Qiu, D. (2019). A High Boost Active Switched Quasi-Z-Source Inverter with Low Input Current Ripple. IEEE Transactions on Industrial Informatics.

[9] Pan, X., Pang, Z., Liu, Y., Yin, S., \& Ju, C. (2019). Enhanced-Boost Bi-directional Qu asi Z-Source Inverter with Novel Active Switched Inductor Cells. IEEE Journal of Emerging and Selected Topics in Power Electronics. 
Enhanced Step Up Energetic-Turn on Capacitor/Turn on-Inductor Quasi-Z-Source Inverters for Commercial Applications

[10] Ahmad, A., \& Singh, R. K. (2018). Analysis of Single-Phase Modified Quasi-Switched Boost ZSI and Extended Quasi-Switched Boost ZSI. In 2018 IEEE Industry Applications Society Annual Meeting (IAS) (pp. 1-6). IEEE.

[11] Abdelhakim, A., Blaabjerg, F., \& Mattavelli, P. (2019). Single-Phase Quasi-Z-Source Inverters: Switching Loss Reduction Using a Quasi-Sinusoidal Modulation Strategy. In 2019 IEEE Applied Power Electronics Conference and Exposition (APEC) (pp. 19181925). IEEE. 